\title{
Artificial Neural Network Modelling of Multi-system Dynamic Adsorption of Organic Pollutants on Activated Carbon
}

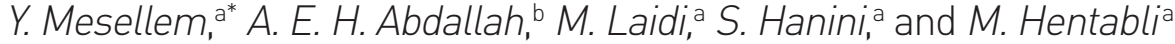 \\ a Laboratory of Biomaterials and Transport Phenomena (LBMPT), \\ University Yahia Fares of Médéa, Algeria \\ ${ }^{\mathrm{b}}$ Faculty of Science, University Saad Dahleb of Blida (USDB-1-), Somaa, Blida, Algeria
}

This work is licensed under Commons Attribution 4.0

\begin{abstract}
The aim of this work was to model multi-system dynamic adsorption using an artificial intelligence technique. A set of data points, collected from scientific papers containing the dynamic adsorption kinetics on activated carbon, was used to build the artificial neural network (ANN). The studied parameters were molar mass, initial concentration, flow rate, bed height, particle diameter, BET surface area, average pore diameter, time, and concentration of dimensionless effluents. Results showed that the optimized ANN was obtained with a high correlation coefficient, $R=0.997$, a root mean square error of RMSE $=0.029$, and a mean absolute deviation of AAD $(\%)=1.810$ during the generalisation phase. Furthermore, a sensitivity analysis was also conducted using the inverse artificial neural network method to study the effect of all the inputs on the dynamic adsorption. Also in this work, the traceability of the estimated results was conducted by developing a graphical user interface.
\end{abstract}

\section{Keywords}

Artificial neural network, dynamic adsorption, organic pollutants, activated carbon

\section{Introduction}

Industrialization is vital to sustainable development, and water resource management is essential in protecting the environment. However, the increase in world population leads to industrial growth and low quality wastewater containing pollutants harmful to human health and the environment. ${ }^{1}$ The wastewater generated in industrial processes requires the use of pre-treatment methods and processes to reduce and/or eliminate all types of pollutants before discharge of the effluent into nature ${ }^{2}$. Wastewaters travel through the treatment plants to remove pollutants from them. Most of the wastewaters contain many substances that could be categorised into organic and inorganic pollutants. ${ }^{3}$ Most of the organic pollutants in industrial effluents are difficult to analyse and cannot be treated using conventional methods. ${ }^{4,5}$ This is due to the unlimited flow rates and excessively high concentrations, and their presence could cause significant environmental damage and health risks. Several studies and research have been conducted on the removal of these environmental organic pollutants using various physical and chemical methods. These methods include chemical precipitation, oxidation, ion exchange, coagulation/flocculation, solvent extraction, membrane separation, and adsorption. ${ }^{6,7}$ Dynamic and/ or fixed bed adsorption is one of the most widely used processes in the environmental applications of chemical industries, especially for the separation and purification of effluents, due to its high efficiency, low cost, and easy operation. ${ }^{8,9}$ The dynamic conduct of a fixed-bed column is described according to the breakthrough curve resulting from the adsorbent-adsorbate system analysis. ${ }^{8,10}$

* Corresponding author: Dr Yamin Mesellem

Email:yaminemselem@gmail.com
Artificial neural networks (ANNs) have also proven to be a suitable modelling tool to deal with complicated problems, especially when physical phenomena are present within the system. ${ }^{11,12}$ (ANN) models can also be used as an alternative prediction method in analysis and engineering. They work like "black box" models, and require no detailed information about the system. ${ }^{13}$ In many applications, ANNs have proven to be a valuable tool for creating databased empirical models. The great number of scientific papers that are being published recently, containing experimental data about the adsorption process, reflects the importance of this phenomenon; therefore, it is of the highest interest to exploit these results available in the literature. They can be used for development, monitoring, and design of the separation process with the help of informatics tools, where the spearhead of any innovative technique is modelling, optimisation, and simulation. Among these applications found in the literature, ANNs have been applied to describe the dynamic, $p$-nitrophenol, ${ }^{14}$ the complex system, ${ }^{15}$ and multi-component system of heavy metals, ${ }^{16,17}$ with the adsorption process.

The aim of this research was to develop a multi-layer ANN to predict the dynamic adsorption of the adsorbent-adsorbate system consisting of 15 components as organic pollutants in the presence of multi-characteristic activated carbon under different operating conditions using the largest and most representative database in comparison with other studies. The performance of the ANN model was evaluated using classical analysis methods; the correlation coefficient $(R)$, statistical root mean square error (RMSE), and average absolute deviation (AAD). 


\section{Materials and methods}

\subsection{Artificial neural networks (ANNs)}

ANNs are defined by a set of algorithms graphically derived from the performance of biological neurons, and have many uses for process modelling and analysis, as well as for predicting a particular system. ${ }^{18}$ They are characterised by simple processing units known as nodes that perform certain mathematical functions. They are also known for their similarity to the structure of the human brain, having the potential to learn (store experimental knowledge) and automatically extract rules from complicated data..$^{19,20}$ The architecture of ANN consists of one or more hidden input layer(s), and an output layer. Each layer of the network consists of neurons, which are inter-connected processing elements. Each neuron is connected to all the neurons in the next layer. The output of the neural network is given by the output layer for the given input data. ${ }^{21,22}$ The hidden layers enable these networks to compute complicated relations between inputs and outputs. The architecture of the ANN model is shown in Fig. 1.

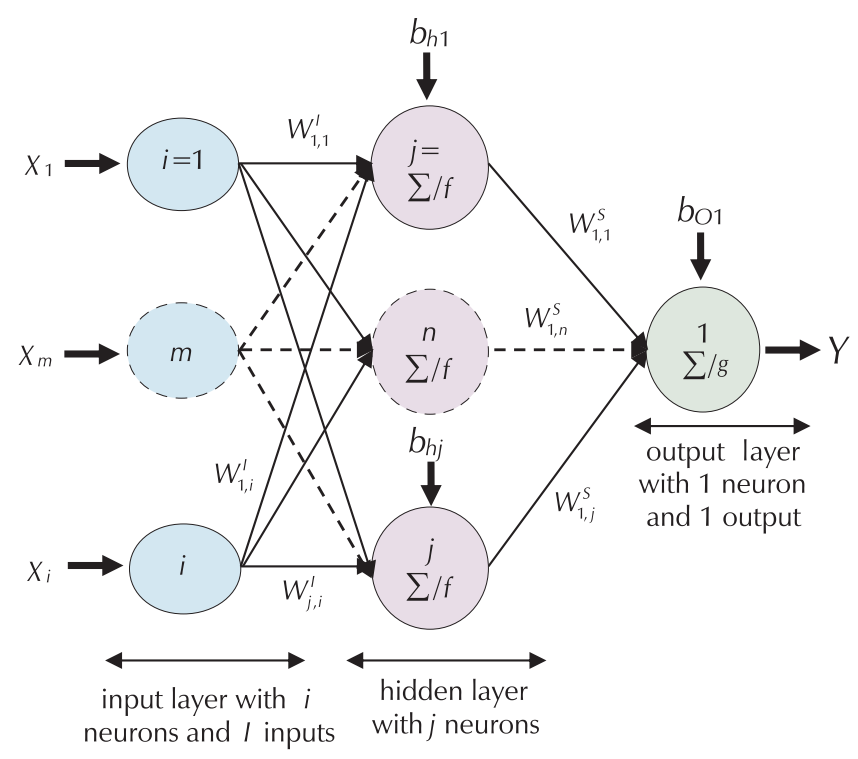

Fig. 1 - Architecture of ANN

The mathematical expression between the input vector $X_{i}$ and output vector $Z_{j}$ of this element (Fig. 1) can be defined as follows: 23,24

$$
Z_{j}=f\left(\sum_{i=1}^{i} W_{j, i}^{\prime} X_{i}+b_{h j}\right)
$$

where $f(x)$ is the linear or nonlinear transfer function, $Z_{j}$ is the output from the hidden layers, and $\left(W_{i, i}^{\prime} X_{i}\right)$ are weighted outputs from the preceding layer as its input result. It propagates the resulting value to output $Y$ :

$$
Y=g\left(\sum_{j=1}^{j} W_{1, j}^{s} Z_{j}+b_{O 1}\right)
$$

Combining Eqs. 1 and 2, the relation between the output $Y$ and the inputs $X_{i}$ of the ANN is obtained:

$$
Y=g\left(\sum_{j=1}^{j} W_{1, j}^{S} f\left(\sum_{i=1}^{i} W_{j, i}^{\prime} X_{i}+b_{h j}\right)+b_{O 1}\right)
$$

Shown below are three transfer functions that are the most commonly used for back-propagation (BP). ${ }^{23}$

The logarithmic sigmoid transfer function (logsig):

$$
f(x)=\frac{1}{1+e^{-x}}
$$

The hyperbolic tangent sigmoid transfer function (tansig):

$$
f(x)=\frac{e^{x}-e^{x}}{e^{x}+e^{x}}
$$

The pure linear transfer function (purelin):

$$
f(x)=x
$$

The procedure for updating the synaptic weights is called back-propagation (BP). BP refers to the way error computed at the output side is propagated backward from the output to the hidden layer(s), and finally to the input layer. ${ }^{23}$

\subsection{Data collection, pre-treatment, and analysis}

In this study, an experimental database of 15 systems, counting [5951 points, 9 variables], was collected from previously published works in literature. ${ }^{25-41}$ Details of the studied adsorption systems are presented in Table 1. The database contained eight input parameters: molar mass $(M)$, initial concentration $\left(C_{0}\right)$, flow rate $(Q)$, bed height $(H)$, particle diameter $\left(d_{p}\right)$, specific surface area $(B E T)$, average pore diameter $\left(D_{\mathrm{p}}\right)$, time $(t)$, and an output parameter which is the dimensionless effluent concentration $\left(c / c_{0}\right)$. The input and output variables were chosen according to the interactions between organic compound proprieties, adsorbent characteristics, and dynamic adsorption operating conditions.

The used database for the ANN model is shown in Table 2.

Linear scaling in the range of $[-1,+1]$ was used in the present study by calculating the minimum and maximum of each variable vector and scaling the data with respect to these limits. Normalisation function used in this work is given by Eq. 7 , and it was programmed in MATLAB as (mapminmax, $[-1,+1]):{ }^{42-44}$

$$
X_{\text {norm }}=2\left(\frac{X_{i}-X_{\text {min }}}{X_{\text {max }}-X_{\text {min }}}\right)-1
$$

where $X_{i}$ is the input or output variable $X$, and $X_{\min }$ and $X_{\max }$ are the minimum and maximum values of variable $X$. 
Table 1 - Systems organic pollutants and the number of experimental data points used in this work

\begin{tabular}{c|c|c|c|c}
\hline $\mathrm{N}^{\circ}$ & Systems & Brute formula & $\begin{array}{c}\text { Experimental } \\
\text { data points }\end{array}$ & Refs. \\
\hline 1 & Phenol & $\mathrm{C}_{6} \mathrm{H}_{5} \mathrm{OH}$ & 2935 & $25,26,34-38$ \\
\hline 2 & Parachlorophenol & $\mathrm{C}_{6} \mathrm{H}_{5} \mathrm{ClO}$ & 456 & 39 \\
\hline 3 & Orthochlorophenol & $\mathrm{C}_{6} \mathrm{H}_{5} \mathrm{ClO}$ & 126 & 36 \\
\hline 4 & Paranitrophenol & $\mathrm{C}_{6} \mathrm{H}_{5} \mathrm{NO}_{3}$ & 312 & 36,40 \\
\hline 5 & Toluene & $\mathrm{C}_{7} \mathrm{H}_{8}$ & 366 & 27,41 \\
\hline 6 & Orthoxylene & $\mathrm{C}_{8} \mathrm{H}_{10}$ & 158 & 27 \\
\hline 7 & Benzene & $\mathrm{C}_{6} \mathrm{H}_{6}$ & 152 & 27 \\
\hline 8 & Benzaldehyde & $\mathrm{C}_{7} \mathrm{H}_{6} \mathrm{O}$ & 280 & 28 \\
\hline 9 & Caffeine & $\mathrm{C}_{8} \mathrm{H}_{10} \mathrm{~N}_{4} \mathrm{O}_{2}$ & 146 & 29 \\
\hline 10 & Diclofenac & $\mathrm{C}_{14} \mathrm{H}_{11} \mathrm{Cl}_{2} \mathrm{NO}_{2}$ & 66 & 29 \\
\hline 11 & 2,4-dichloro- & $\mathrm{C}_{8} \mathrm{H}_{6} \mathrm{Cl}_{2} \mathrm{O}_{3}$ & 140 & 30 \\
\hline 12 & Fhenoxyacetic acid & $\mathrm{C}_{14} \mathrm{H}_{12} \mathrm{FNO}_{3}$ & 302 & 31 \\
\hline 13 & Ciprofloxacin & $\mathrm{C}_{17} \mathrm{H}_{18} \mathrm{FN}_{3} \mathrm{O}_{3}$ & 170 & 32 \\
\hline 14 & Norfloxacin & $\mathrm{C}_{16} \mathrm{H}_{18} \mathrm{FN}_{3} \mathrm{O}_{3}$ & 171 & 32 \\
\hline 15 & Levofloxacin & $\mathrm{C}_{18} \mathrm{H}_{20} \mathrm{FN}_{3} \mathrm{O}_{4}$ & 171 & 33 \\
\hline & & & & \\
\hline
\end{tabular}

\subsection{Model performance evaluation}

The performance of the ANN model was evaluated using the following statistical parameters, ${ }^{45-47}$ as expressed below for the correlation coefficient $(R)$ :

$$
R=\frac{\sum_{i=1}^{N}\left(\left(\frac{C}{C_{0}}\right)_{i, \exp }-\overline{\left(\frac{C}{C_{0}}\right)_{i, \exp }}\right)\left(\left(\frac{C}{C_{0}}\right)_{i, \mathrm{cal}}-\overline{\left(\frac{C}{C_{0}}\right)_{i, \mathrm{cal}}}\right)}{\sqrt{\sum_{i=1}^{N}\left(\left(\frac{C}{C_{0}}\right)_{i, \exp }-\overline{\left(\frac{C}{C_{0}}\right)_{i, \exp }}\right)^{2} \sum_{i=1}^{N}\left(\left(\frac{C}{C_{0}}\right)_{i, \mathrm{cal}}-\overline{\left(\frac{C}{C_{0}}\right)_{i, \mathrm{cal}}}\right)^{2}}}
$$

and for the root mean square error for (RMSE) presented by the following expression:

$$
\mathrm{RMSE}=\sqrt{\frac{1}{N} \sum_{i=1}^{N}\left(\left(\frac{C}{C_{0}}\right)_{i, \exp }-\left(\frac{C}{C_{0}}\right)_{i, \mathrm{cal}}\right)^{2}}
$$

and for the average absolute deviation of (AAD) as follows:

$$
\operatorname{AAD}(\%)=\frac{1}{N} \sum_{i=1}^{N}\left|\left(\frac{C}{C_{0}}\right)_{i, \exp }-\left(\frac{C}{C_{0}}\right)_{i, \text { cal }}\right|
$$

where $i$ is the number of data points,

$\left(\frac{C}{C_{0}}\right)_{i, \exp }$ is the experimental reduced concentration, and $\left(\frac{C}{C_{0}}\right)_{i, \text { cal }}$ is the reduced concentration predicted by the ANN model.

\section{Results and discussion}

\subsection{ANN predictive model}

The Artificial Neural Network (ANN) model was developed with back-propagation learning algorithms to predict the dynamic adsorption of a complex system.

In this study, the database was randomly divided into three groups: training, test, and validation set, composed of $80 \%, 10 \%$, and $10 \%$, respectively. Since there was no rule to determine the number of neurons in the hidden layers, a test and trial method was adopted in this work by repeating each architecture twenty times to avoid overfitting problem.

The optimised ANN architecture consisted of $\{8-45-1\}$, which means eight inputs forty-five neurons in the hidden layer and one output, as is shown in Fig. 2. The best ANN was found with the logarithmic sigmoid (logsig) given in Eqs. (4), and tangent hyperbolic (tansig) given in Eqs. (5)

\begin{tabular}{|c|c|c|c|c|c|c|}
\hline Statistical analysis & Parameters & Unit & Minimum & Maximum & Mean & Standard deviation \\
\hline \multirow{8}{*}{ Inputs } & molar mass & $\mathrm{g} \mathrm{mol}^{-1}$ & 78.11 & 361.37 & 137.29 & 77.39 \\
\hline & initial concentration & $\left.m g\right|^{-1}$ & 0.00019 & 500 & 108.86 & 104.06 \\
\hline & flow rate & $\mathrm{ml} \mathrm{\operatorname {min } ^ { - 1 }}$ & 0.05 & 456.62 & 206.83 & 567.48 \\
\hline & bed height & $\mathrm{cm}$ & 2 & 200 & 32.58 & 54.064 \\
\hline & particle diameter & $\mathrm{mm}$ & 0.1 & 2.4 & 0.80 & 0.5514 \\
\hline & specific surface area & $m^{2} g^{-1}$ & 678 & 2869 & 981.40 & 409.04 \\
\hline & average pore diameter & $\mathrm{nm}$ & 1.29 & 3.15 & 2.15 & 0.652 \\
\hline & time & $\min$ & 0 & 57170 & 1991.21 & 6023.77 \\
\hline Output & dimensionless effluent concentration & - & 0 & 1 & 0.51 & 0.3819 \\
\hline
\end{tabular}
transfer functions for the hidden and the output layers, re-

Table 2 - Statistical analysis of input and output data used in this work 


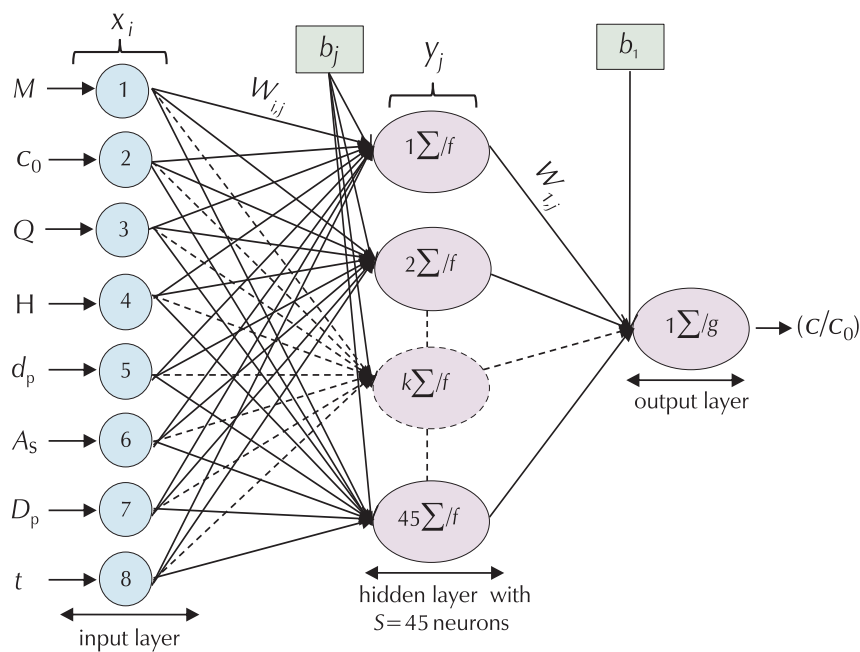

Fig. 2 - Optimal structure of ANN model, containing 45 neurons

spectively. The output of each hidden neuron $\left(Y_{i}\right)$ is calculated as:

$$
Y_{i}=f\left[\sum_{i=1}^{45} w_{i, j} x_{i}+b_{j}\right]=\frac{1}{1+\exp \left(\sum_{i=1}^{45} w_{i, j} x_{i}+b_{j}\right)}
$$

while the output of the network is given by:

$$
\begin{gathered}
\frac{c}{c_{0}}=f\left[\sum_{j=1}^{45} w_{1, j} y_{j}+b_{1}\right]= \\
=\frac{\exp \left(\sum_{j=1}^{45} w_{1, j} y_{j}+b_{1}\right)-\exp \left(\sum_{j=1}^{45} w_{1, j} y_{j}+b_{1}\right)}{\exp \left(\sum_{j=1}^{45} w_{1, j} y_{j}+b_{1}\right)+\exp \left(\sum_{j=1}^{45} w_{1, j} y_{j}+b_{1}\right)}
\end{gathered}
$$

\begin{tabular}{|c|c|c|c|c|}
\hline Studied parameters & $R(\max )$ & RMSE (min) & AAD \% (min) & Selected parameters \\
\hline \multicolumn{5}{|c|}{ Learning algorithms } \\
\hline $\begin{array}{l}\text { Levenberg-Marquardt } \\
\text { backpropagation }\end{array}$ & 0.997 & 0.029 & 1.810 & $\begin{array}{l}\text { Levenberg-Marquardt } \\
\text { backpropagation }\end{array}$ \\
\hline \multicolumn{5}{|c|}{ Activation functions (hidden neurons/output neurons) } \\
\hline Logarithmic sigmoid-sigmoid & 0.793 & 0.290 & 21.072 & \multirow{6}{*}{$\begin{array}{l}\text { Logarithmic sigmoid-tangent } \\
\text { hyperbolic }\end{array}$} \\
\hline Logarithmic sigmoid-linear & 0.937 & 0.134 & 10.012 & \\
\hline Logarithmic sigmoid-tangent hyperbolic & 0.997 & 0.029 & 1.810 & \\
\hline Tangent hyperbolic-logarithmic sigmoid & 0.893 & 0.274 & 18.702 & \\
\hline Tangent hyperbolic-linear & 0.963 & 0.103 & 6.644 & \\
\hline $\begin{array}{l}\text { Tangent hyperbolic-tangent hyperbolic } \\
\text { Linear-linear } \\
\text { Linear- logarithmic sigmoid } \\
\text { Linear-tangent hyperbolic }\end{array}$ & $\begin{array}{l}0.995 \\
0.238 \\
0.496 \\
0.489\end{array}$ & $\begin{array}{l}0.035 \\
0.360 \\
0.338 \\
0.351\end{array}$ & $\begin{array}{r}2.063 \\
32.298 \\
28.777 \\
26.890\end{array}$ & \\
\hline \multicolumn{5}{|c|}{ Number of neurons in the hidden layer } \\
\hline Changed from 8 to 50 & 0.997 & 0.029 & 1.810 & 45 neurons \\
\hline
\end{tabular}

Table 3 - Selected parameters of the optimal multi-layer perception ANN model
In Eqs. (11) and (12): $w_{i, j}$ is the weight of the connections between the input and the hidden neurons, $x_{i}$ are the input variables (relevant descriptors), $b_{j}$ is the bias on the hidden neuron similarly, $w_{1}$, represents the weight of the connections between the hidden and output neuron, and $b_{1}$ is the bias on the output neuron.

The results showed that the ANN with one hidden layer was the best. Tests conducted for more than one of the hidden layers and different parameters showed no significant improvement. Table 3 shows the structure of the improved ANN model to obtain the highest correlation coefficient closer to 1 , with the minimum RMSE error closer to 0 . The linear regression parameters were obtained directly using the postreg MATLAB R2018a function.

The performance of the optimised network was evaluated for each epoch in the training through mean square error (MSE). Evolution of the mean square error for the training, validation, and testing stage vs. the number of epochs is shown in Fig. 3. The best ANN was found with a very acceptable validation performance at 4892 epochs, indicating an accurate mapping of the experimental data.

Fig. 4 represents the regression plot of the whole database, validation, and test subset. Results shown in Table 3 suggest high performance of the optimised ANN with a correlation coefficient of $R=0.997$, root mean square error of RMSE $=0.029$, and the absolute deviation of AAD $(\%)=1.810$. It can be observed that ANN was able to capture the adsorption dynamics very well.

Detailed comparison between the calculated and the experimental values of each system in terms of correlation coefficient $(R)$, root mean square error (RMSE), and average absolute deviation (AAD) is presented in Table 4.

Figs. 5 to 9 show comparison curves between experimental and ANN-predicted values illustrated in empty and full geometric shapes, respectively, of dynamic adsorption of 


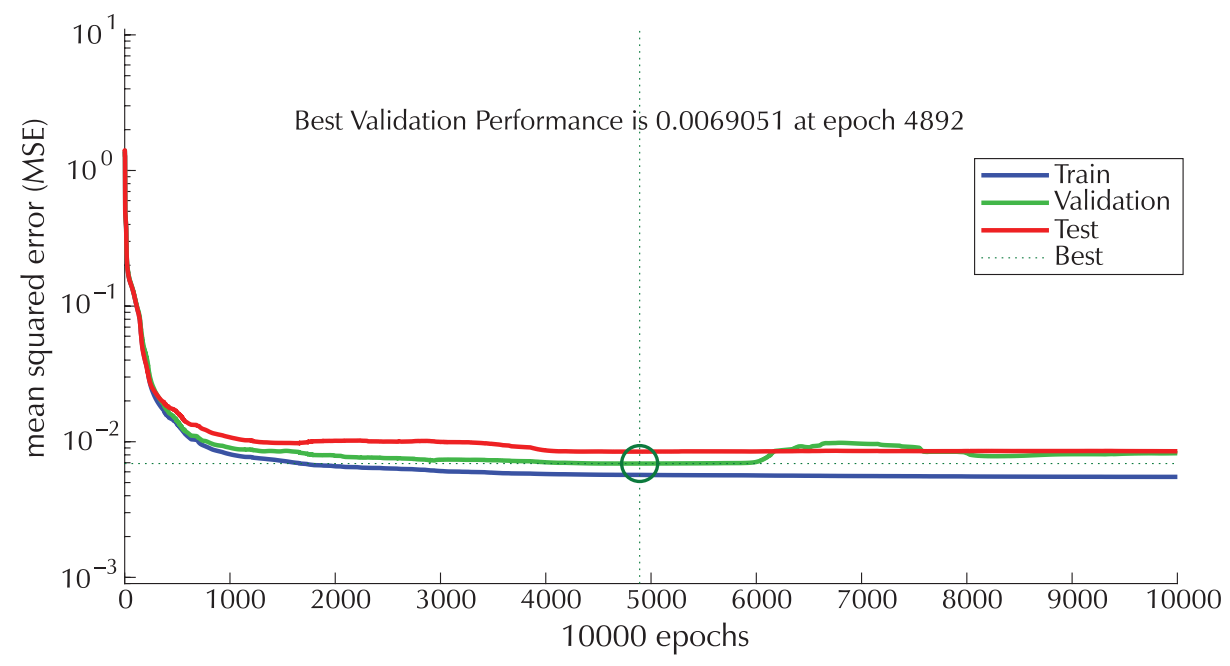

Fig. 3 - Profiles of the MSE during training, validation, and testing stage vs. the number of epochs for the best network topology
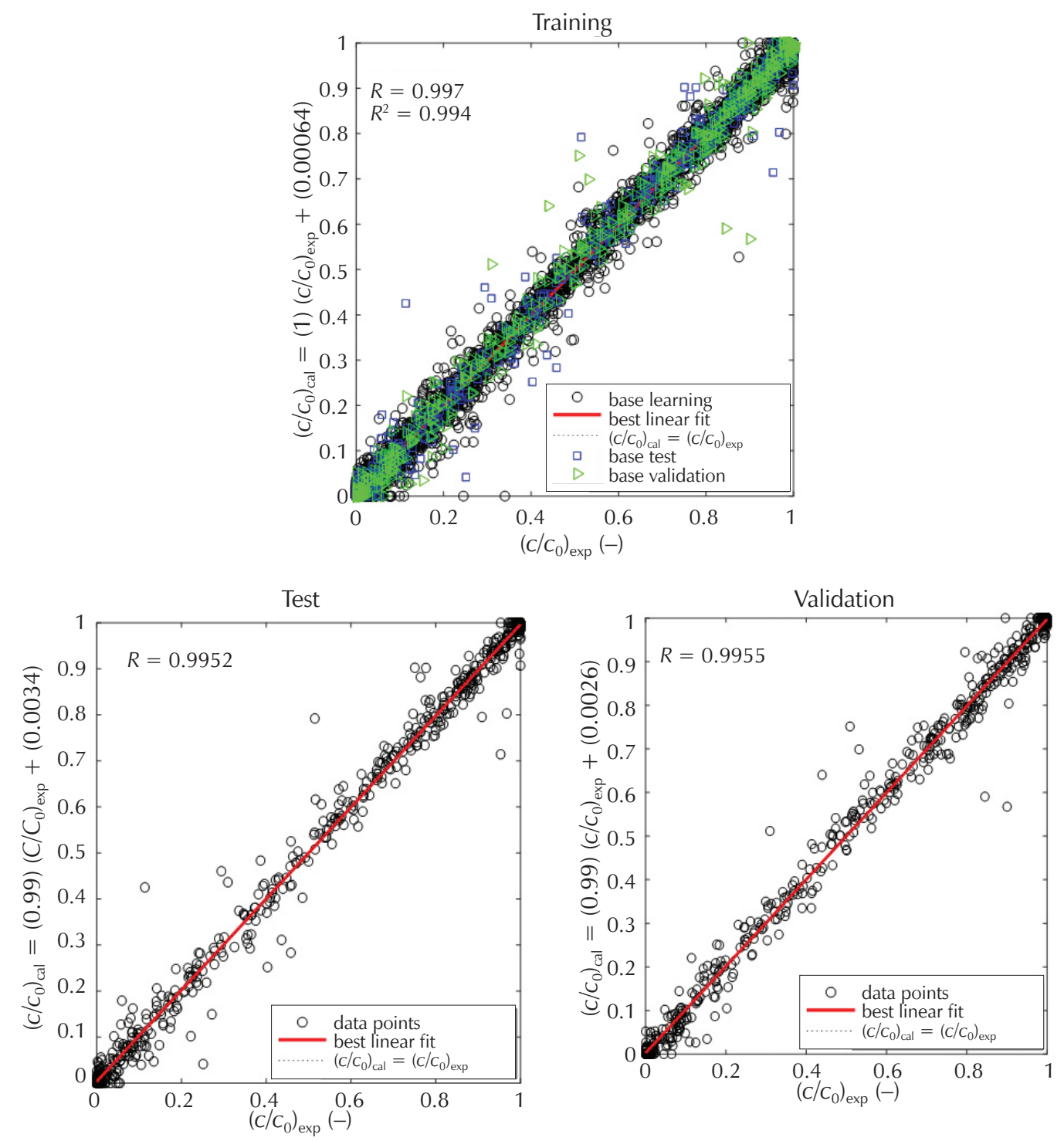

Fig. 4 -Comparison between experimental and calculated values for the whole dataset, validation, and test 
different adsorbate systems on activated carbon under different operating conditions. Results show very good agreement and good prediction ability of the ANN model. Fig. 5 represents the comparison between the experimental and the predicted dimensionless effluent concentration of dynamic adsorption of phenol system on activated carbon at various average pore diameters, initial concentration, and bed height at various flow rates.

Table 4 - Detailed comparison of the correlation coefficient $(R)$, root mean square error (RMSE), and the average absolute deviation (AAD) of each system

\begin{tabular}{c|c|c|c}
\hline System & $R$ & RMSE & AAD \% \\
\hline Phenol & 0.998 & 0.023 & 1.337 \\
\hline Parachlorophenol & 0.997 & 0.026 & 1.999 \\
\hline Orthochlorophenol & 0.993 & 0.050 & 2.533 \\
\hline Paranitrophenol & 0.994 & 0.043 & 2.520 \\
\hline Toluene & 0.998 & 0.027 & 1.857 \\
\hline Orthoxylene & 0.994 & 0.028 & 2.125 \\
\hline Benzene & 0.995 & 0.030 & 2.399 \\
\hline Benzaldehyde & 0.998 & 0.024 & 1.931 \\
\hline
\end{tabular}

\begin{tabular}{|c|c|c|c|}
\hline System & $R$ & RMSE & AAD \% \\
\hline Caffeine & 0.995 & 0.041 & 2.312 \\
\hline Diclofenac & 0.995 & 0.032 & 2.578 \\
\hline 2,4-Dichlorophenoxyacetic acid & 0.998 & 0.021 & 1.674 \\
\hline Flumequine & 0.981 & 0.054 & 3.414 \\
\hline Ciprofloxacin & 0.995 & 0.032 & 2.377 \\
\hline Norfloxacin & 0.996 & 0.029 & 2.153 \\
\hline Levofloxacin & 0.996 & 0.029 & 2.139 \\
\hline Total & $\mathbf{0 . 9 9 5}$ & $\mathbf{0 . 0 3 2}$ & $\mathbf{2 . 2 2 5}$ \\
\hline
\end{tabular}
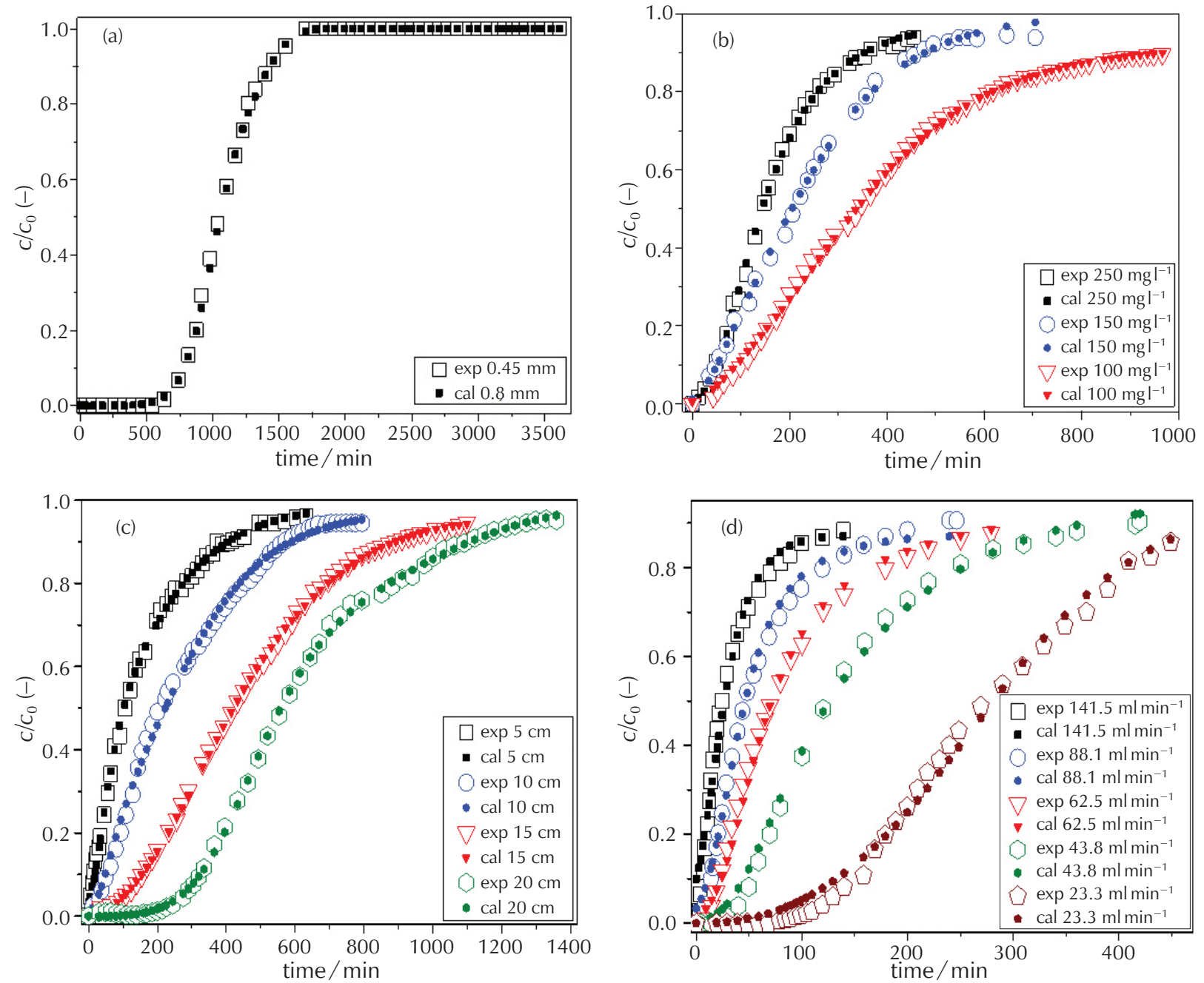

Fig. 5 - Experimental dynamic adsorption of a Phenol system on activated carbon by the ANN model (a): at various average pore diameters; (b): at various initial concentrations; (c): at various bed heights; (d): at various flow rates 

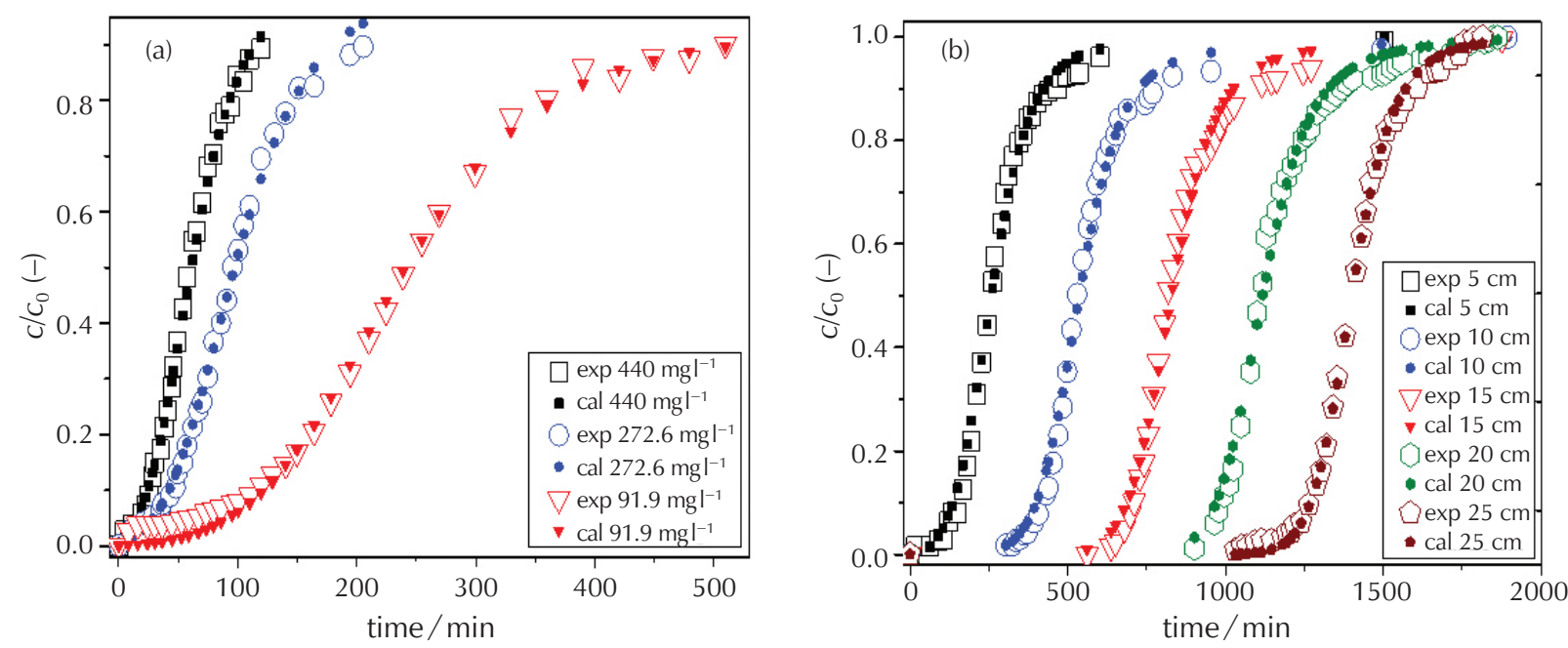

Fig. 6 - Comparison between experimental and predicted values of dynamic adsorption of (a) Benzaldehyde at various initial concentrations, (b) Parachlorophenol system at various bed heights
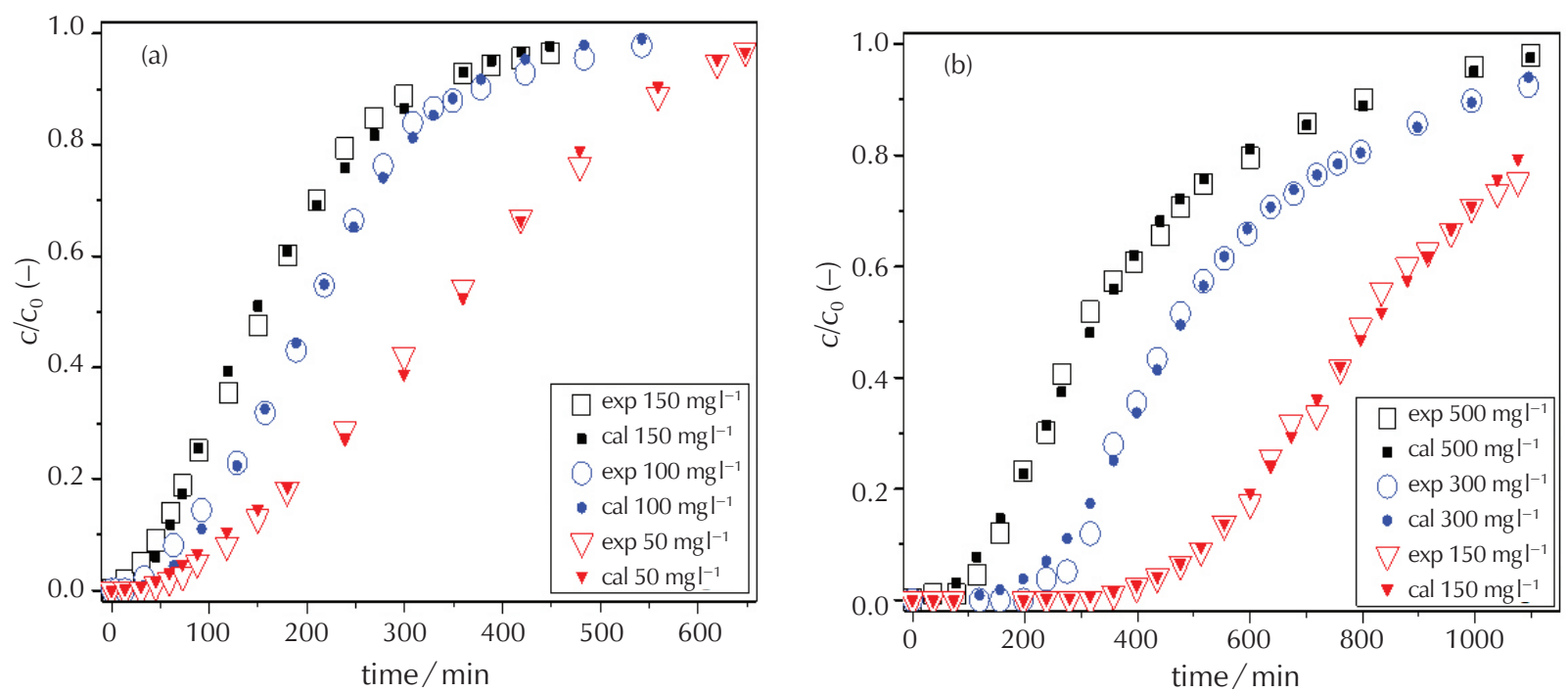

Fig. 7 - Comparison between experimental and predicted values of dynamic adsorption on activated carbon of (a) 2,4-Dichlorophenoxyacetic acid system, and(b) Paranitophenol system at various initial concentrations

Fig. 6 shows a comparison between experimental and predicted dimensionless effluent concentration of Benzaldehyde at various initial concentrations, and Parachlorophenol system at various bed heights. Results show the ability of the ANN model to predict the dimensionless effluent concentration with high accuracy.

Figs. 7 shows comparison between experimental and predicted values of dynamic adsorption on activated carbon of (a) 2,4-Dichlorophenoxyacetic acid system, and (b) Paranitrophenol system at various initial concentrations. Fig 8 shows a comparison between experimental and predicted values of dynamic adsorption on activated carbon of (a) Toluene system at various flow rates, and (b) Orthoxylene system at various bed heights. Results show a very high performance of the developed model in following the trend of the experimental value with high accuracy.
The last comparison, plotted in Fig. 9, of Norfloxacin, Ciprofloxacin, and Levofloxacin systems was conducted with the same three initial concentration values. Results show the ability of the ANN to model dimensionless effluent concentration of different dynamic adsorption systems at various operating conditions with high performance.

\subsection{Sensitivity analysis}

Sensitivity analysis is a critical tool for the determination of the relative importance of each input on the output variable. A sensitivity study was conducted by programming the Garson equation ${ }^{48}$ in MATLAB software, and using the best model architecture $\{8,45,1\}$ and parameters \{weight matrix and vectors biases $\}$. 

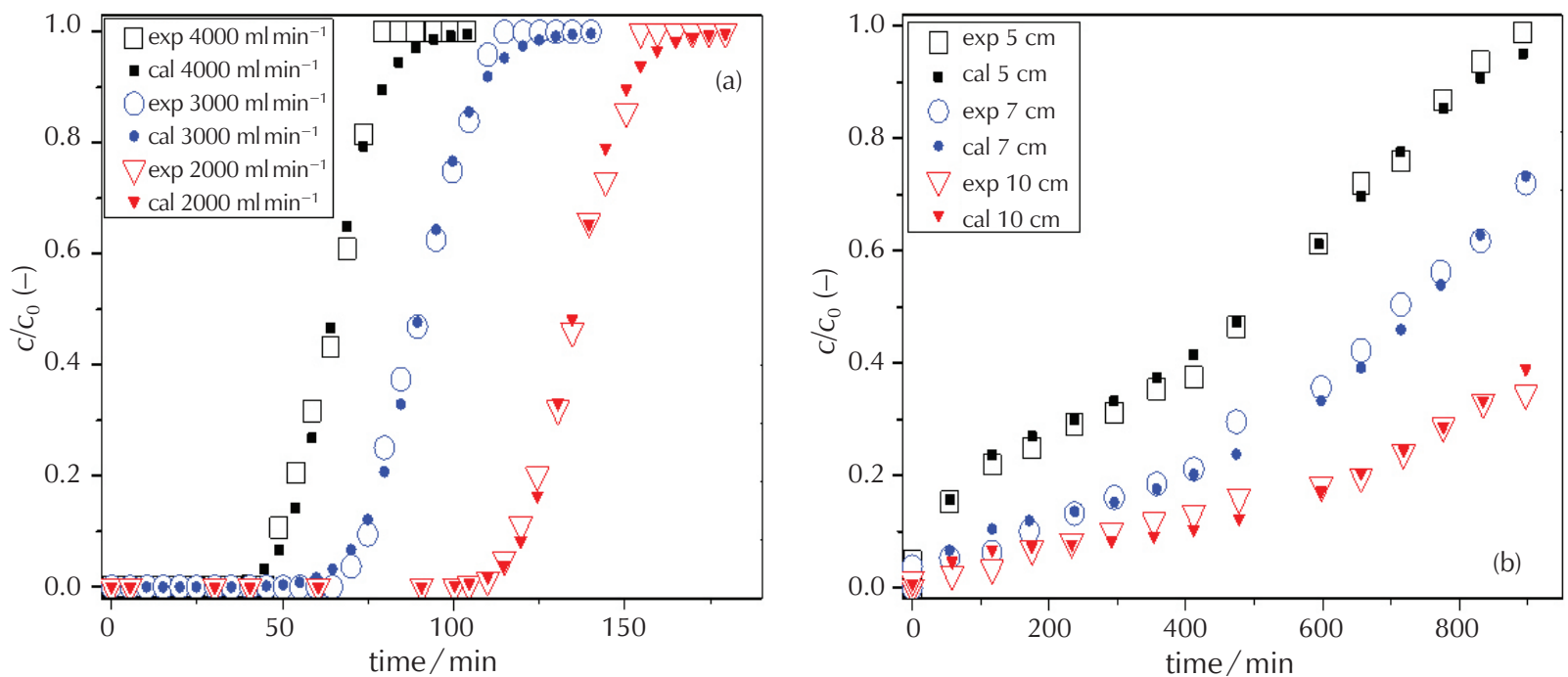

Fig. 8 - Comparison between experimental and predicted values of dynamic adsorption on activated carbon of (a) Toluene system at various flow rates, and (b) Orthoxylene system at various bed heights
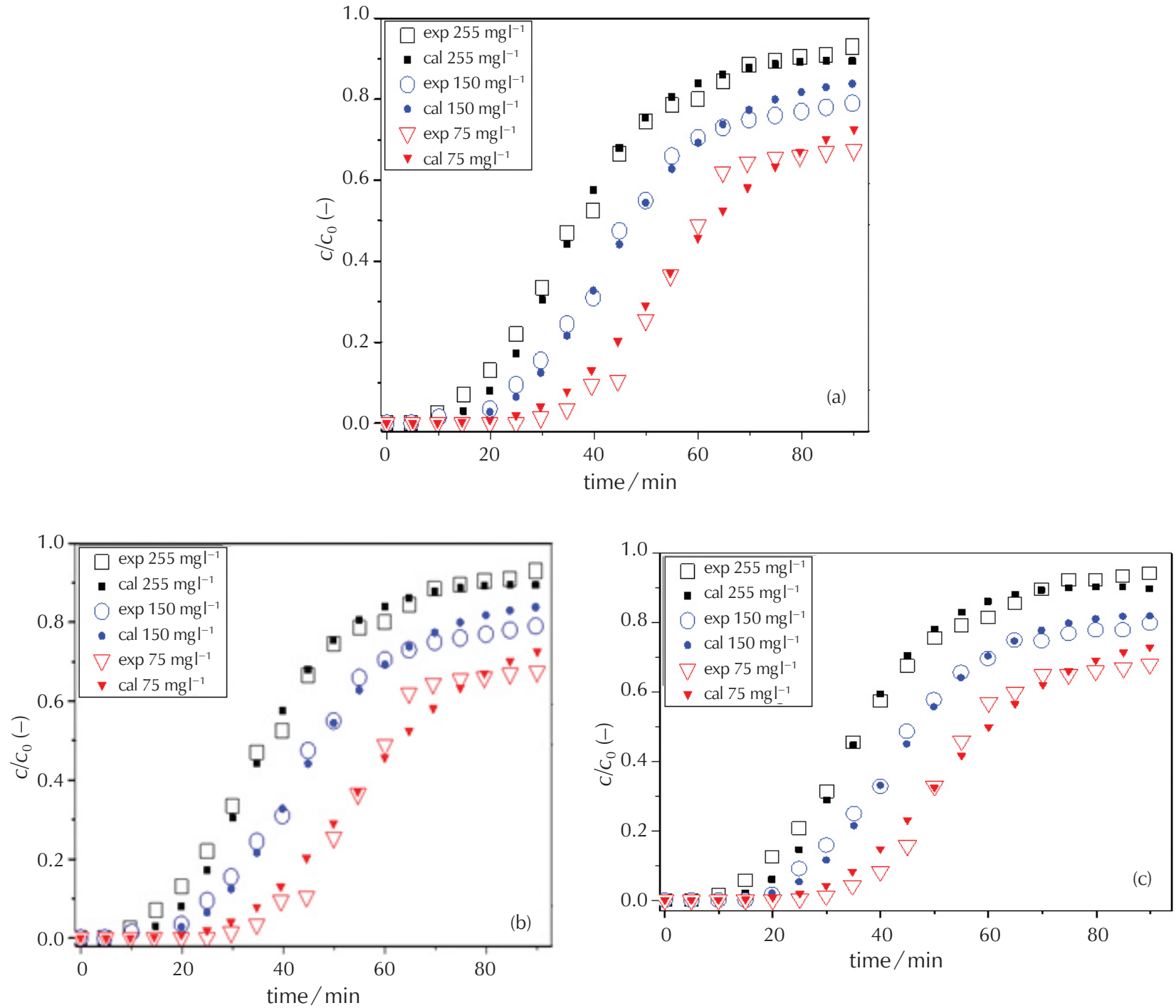

Fig. 9 - Comparison between experimental and predicted values of dynamic adsorption on activated carbon of (a) Norfloxacin, (b) Ciprofloxacin, and (d) Levofloxacin system, at various initial concentrations 


$$
I_{j}=\frac{\sum_{m=1}^{m=N_{h}}\left(\left(\frac{\left|W_{j m}^{\text {ih }}\right|}{\sum_{k=1}^{N_{i}}\left|W_{k m}^{\text {ih }}\right|}\right) \times\left|W_{m n}^{\text {ho }}\right|\right)}{\sum_{k=1}^{k=N_{i}}\left(\sum_{m=1}^{m=N_{h}}\left(\frac{\left|W_{k m}^{i h}\right|}{\sum_{k=1}^{N_{i}}\left|W_{k m}^{\text {ih }}\right|}\right) \times\left|W_{m n}^{\text {ho }}\right|\right)}
$$

where $I_{j}$ is the relative importance of the $j$ input variable on the output variable; $N_{i}$ and $N_{h}$ are the number of input and hidden neurons, respectively; $w$ are the connection weights; the superscripts $i, h$, and $o$ refer to input, hidden, and output layers, respectively; and subscripts $k, m$, and $n$ refer to input, hidden, and output neurons, respectively. ${ }^{48,49}$ The contribution of the input variables obtained by the 'weight' method for the neural network is shown in Fig. 10 .

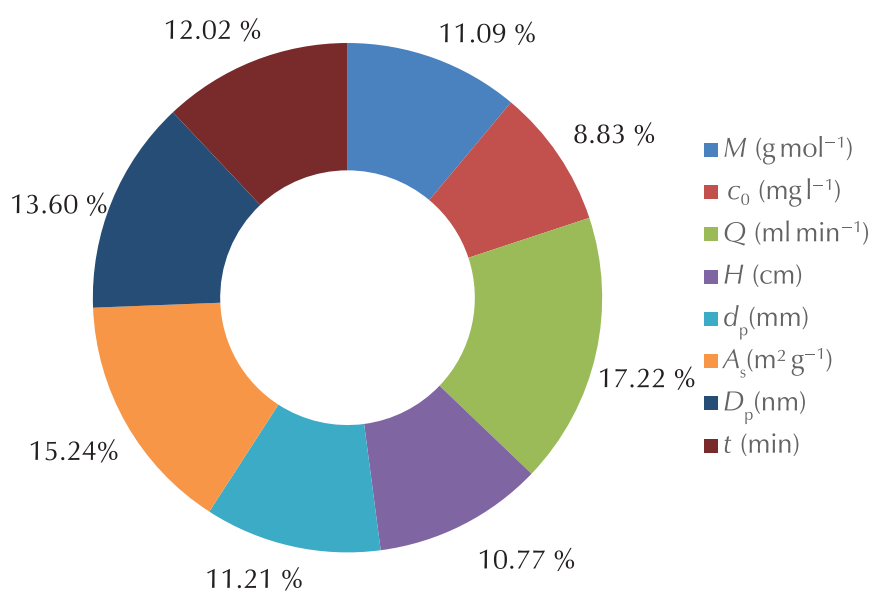

Fig. 10 - Pie chart depicting the relative importance of the input variables, on dynamic adsorption of organic pollutants on activated carbon

Fig. 10 shows that all input variables have an impact on adsorption dynamics of organic pollutants on activated carbon with relative importance higher than $5 \%$. The flow rate $(17.22 \%)$, specific surface area $(15.24 \%)$, mean pore diameter $(13.6 \%)$, time $(12.02 \%)$, particle diameter $(11.21 \%)$, molecular weight $(11.09 \%)$, bed height $(10.77 \%)$, and initial concentration (8.83\%) have less effect than other variables.

\section{Program for calculating the effluent concentration}

In order to provide easy computing of effluent concentration, a computer program was designed based on the best ANN architecture \{weights and biases\}. All inputs were normalised and de-normalised via this interface to calculate the dimensionless effluent concentration (Fig. 11).

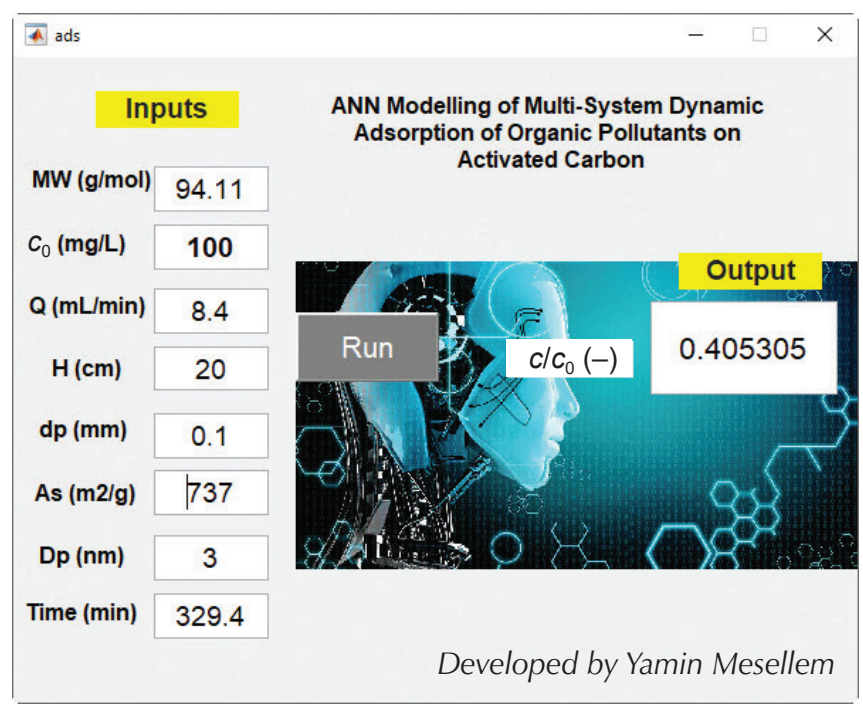

Fig. 11 - MATLAB R2018a interface for effluent concentration computing

\section{Conclusions}

In this work, a methodology was proposed to predict the multi-system dynamic adsorption of organic pollutants on activated carbon. Conclusions are summarised as follows:

- Before using ANN, the database used was collected from experimental data recently published in scientific articles, which include a relevant input matrix of [5951, 8], as follows: molar mass, initial concentration, flow rate, bed height, particle diameter, BET surface area, average pore diameter, and dimensionless effluent concentration as an output.

- Good agreement was shown between the experimental data and the data calculated by the ANN model, the correlation coefficients of the dataset (training, validation, and testing) were greater than 0.99 , plus better robustness $(R=0.997$, RMSE $=0.029$, and $\mathrm{AAD}=1.810 \%)$ for the training group were obtained.

- For determination of the importance of each input variable, a sensitivity analysis was conducted. The results showed that all input parameters had a significant relative importance on the output and could not be neglected.

- Finally, a user-friendly graphical interface was designed based on the optimised ANN parameters.

\section{ACKNOWLEDGEMENT}

The authors would like to thank the team of LBMPT Laboratory for their efforts and encouragement throughout this project in providing the help and data used in this study. The authors also thank the anonymous reviewers for their constructive comments, which helped to improve the quality and presentation of this paper. 


\section{List of symbols}

AAD - average absolute deviation, $\%$

$A_{\mathrm{s}} \quad-$ BET Specific surface area, $\mathrm{m}^{2} \mathrm{~g}^{-1}$

$b_{\mathrm{h} 1} \quad-$ bias of neurons, -

$b_{\mathrm{O} 1} \quad-$ bias of neurons in the output layer, -

$\mathrm{C}_{0} \quad-$ initial concentration, $\mathrm{mgl}^{-1}$

$D_{\mathrm{p}} \quad$ - average pore diameter, $\mathrm{nm}$

$d_{\mathrm{p}} \quad-$ particle diameter, $\mathrm{mm}$

$H \quad$ - bed height, $\mathrm{cm}$

$M \quad-$ molar mass, $\mathrm{g} \mathrm{mol}^{-1}$

MSE - mean square error, -

$C / C_{0} \quad$ - dimensionless effluent concentration, -

Q - flow rate, $\mathrm{ml} \mathrm{min}^{-1}$

$R^{2} \quad$ - regression coefficient, -

$R \quad$ - correlation coefficient, -

RMSE - root mean square error, -

$t \quad-$ time $r$, min

$W_{j, i}^{\prime} \quad$ - matrix weights in the output hidden layer, -

$W_{1, j}^{S} \quad-$ matrix weights in the hidden input layer, -

\section{Sub-index}

ANNs - artificial neural networks

BP - back-propagation

cal - calculated

exp - experimental

LM - Levenberg-Marquardt

\section{References}

\section{Literatura}

1. S. Pandharipande, A. Deshmukh, Artificial neural network approach for modeling of $\mathrm{Ni}(\mathrm{II})$ adsorption from aqueous solution using Aegel marmelos fruits shell absorbent, Int. J. Eng. Sci. Emerg. Technol. 4 (2) (2013) 27-36.

2. N. San, S. Mart, F. Josep, X. F. Segura, A. S. Ferrer, Pre-oxidation of an extremely polluted industrial wastewater by the Fenton's reagent, J. Hazard. Mater. 101 (3) (2003) 315-322. doi: https://doi.org/10.1016/S0304-3894(03)00207-3.

3. G. Zhou, G. Ying, S. Liu, L. Zhou, Z. Chen, Simultaneous removal of inorganic and organic compounds in wastewater by Environmental Science Processes \& Impacts compounds in wastewater by freshwater green, Environ. Sci. Proc. Impact. 16 (2014) 2018-2027, doi: https://doi.org/10.1039/ C4EM00094C.

4. Z. Carmen, S. Daniela, Textile Organic Dyes - Characteristics, Polluting Effects and Separation / Elimination Procedures from Industrial Effluents - A Critical Overview, 2010.

5. Y.-Y. Choi, S.-R. Baek, J.-I. Kim, J.-W. Choi, J. Hur, T.-U Lee, C.-J. Park, B. J. Lee, Characteristics and biodegradability of wastewater organic matter in municipal wastewater treatment plants collecting domestic wastewater and industrial discharge, Water 9 (6) (2017) 409, doi: https://doi. org/10.3390/w9060409.

6. V. Khandegar, A. K. Saroha, Electrocoagulation for the treatment of textile industry effluent - A review, J. Environ. Man.
128 (2013) 949-963, doi: https://doi.org/10.1016/j.jenvman.2013.06.043.

7. M. Sharma, T. Jain, S. Singh, O. P. Pandey, Photocatalytic degradation of organic dyes under UV - Visible light using capped ZnS nanoparticles, Sol. Energy. 86 (1) (2012) 626633, doi: https://doi.org/10.1016/j.solener.2011.11.006.

8. Z. Xu, J. Cai, B. Pan, Mathematically modeling fixed-bed adsorption in aqueous systems, J. Zhejiang Univ. Sci. 14 (3) (2013) 155-176, doi: https://doi.org/10.1631/jzus. A1300029.

9. H. Patel, Fixed-bed column adsorption study: a comprehensive review, Appl. Water Sci. 9 (2019), doi: https://doi. org/10.1007/s13201-019-0927-7.

10. D. I. Sa, J. Lo, R. G. Sa, Correa-Murrieta M.A., Study of a fixed-bed column in the adsorption of an azo dye from an aqueous medium using a chitosan - glutaraldehyde biosorbent, Adsorpt. Sci. Technol. 36 (1-2) (2018) 215-232, doi: https://doi.org/10.1177/0263617416688021.

11. A. Lazrak, F. Boudehenn, S. Bonnot, G. Fraisse, A. Leconte, P. Papillon, B. Souyri, Development of a dynamic artificial neural network model of an absorption chiller and its experimental validation, Renew. Energ. 86 (2016) 1009-1022, doi: https://doi.org/10.1016/j.renene.2015.09.023.

12. O. Isaac, A. Jantan, A. Esther, State-of-the-art in artificial neural network applications: A survey. Heliyon 4 (11) (2018) e00938, doi: https://doi.org/10.1016/j.heliyon.2018. e00938.

13. Z. Zhang, M. W. Beck, D. A. Winkler, B. Huang, W. Sibanda, Opening the black box of neural networks : methods for interpreting neural network models in clinical applications, Ann. Transl. Med. 6 (5) (2018), doi: https://doi.org/10.21037/ atm.2018.05.32.

14. M. Sediri, S. Hanini, H. Cherifi, M. Laidi, S. A. Turki, Dynamic Adsorption Modelling of P-nitrophenol in Aqueous Solution Using Artificial Neural Network, JMES 8 (7) (2017) 22822287, url: https://www.jmaterenvironsci.com/Document/ vol8/vol8_N7/245-JMES-Sediri.pdf.

15. M. Sediri, S. Hanini, M. Laidi, S. Abbas, Artificial Neural Networks Modeling of Dynamic Adsorption From Aqueous Solution, Mor. J. Chem. 5 (2) (2017) 236-243.

16. J. Moreno-Pérez, A. Bonilla-Petriciolet, D. I. Mendoza-Castillo, H. E. Reynel-Avila, Artificial neural network-based surrogate modeling of multi-component dynamic adsorption of heavy metals with a biochar, J. Environ. Chem. Eng. 6 (4) (2018) 5389-5400, doi: https://doi.org/10.1016/j. jece.2018.08.038.

17. M. Yusuf, K. Song, L. Li, Fixed bed column and artificial neural network model to predict heavy metals adsorption dynamic on surfactant decorated graphene, Colloid. Surf. A Physicochem. Eng. Asp. 585 (2020) 124076, doi: https:// doi.org/10.1016/j.colsurfa.2019.124076.

18. S. Agatonovic-Kustrin, R. Beresford, Basic concepts of artificial neural network (ANN) modeling and its application in pharmaceutical research, J. Pharm. Biomed. Anal. 22 (5) (2000) 717-727, doi: https://doi.org/10.1016/S07317085(99)00272-1.

19. A. Rezrazi, S. Hanini, M. Laidi, An optimisation methodology of artificial neural network models for predicting solar radiation : a case study, Theoret. Appl. Climatol. 123 (2016) 769-783, doi: https://doi.org/10.1007/s00704-015-1398-x.

20. M. Berdja, B. Abbad, M. Laidi, F. Yahi, M. Ouali, Numerical simulation of a phase change material (PCM) in a domestic refrigerator powered by photovoltaic energy, in Proceeding Proc. CHT-12. ICHMT Int. Symp. Adv. Comput. Heat Transf. (Begellhouse, Connecticut, 2012), pp. 693-705, doi: https:// doi.org/10.1615/ICHMT.2012.CHT-12.430. 
21. J. P. Rigol, C. H. Jarvis, N. Stuart, Artificial neural networks as a tool for spatial interpolation, Int. J. Geogr. Inf. Sci. 15 (4) (2001) 323-343, doi: https://doi. org/10.1080/13658810110038951.

22. M. Laidi, B. Abbad, M. Berdja, M. Chikh, Performance of a photovoltaic solar container under Mediterranean and arid climate conditions in Algeria, En. Procedia 18 (2012) 14521457, doi: https://doi.org/10.1016/j.egypro.2012.05.163.

23. C. Si-Moussa, S. Hanini, R. Derriche, M. Bouhedda, A. Bouzidi, Prediction of high-pressure vapor liquid equilibrium of six binary systems, carbon dioxide with six esters, using an artificial neural network model, Braz. J. Chem. Eng. 25 (1) (2008) 183-199, doi: https://doi.org/10.1590/S010466322008000100019.

24. M. Hamadache, A. Amrane, O. Benkortbi, S. Hanini, L. Khaouane, C. Si Moussa, Environmental toxicity of pesticides, and its modeling by QSAR approaches, in Adv. QSAR Model. Appl. Pharm. Chem. Food, Agric. Environ. Sci. (2017), pp. 471-501, doi: https://doi.org/10.1007/978-3319-56850-8_13.

25. Y. A. Alhamed, Adsorption kinetics and performance of packed bed adsorber for phenol removal using activated carbon from dates' stones, J. Hazard. Mater. 170 (23) (2009) 763-770, doi: https://doi.org/10.1016/j.jhazmat.2009.05.002.

26. A. C. Lua, Q. Jia, Adsorption of phenol by oil-palm-shell activated carbons in a fixed bed, Chem. Eng. J. 150 (2-3) (2009) 455-461, doi: https://doi.org/10.1016/j.cej.2009.01.034.

27. A. D. Luz, S. M. D. A. Guelli Ulson De Souza, C. Da Luz, R. V. D. P. Rezende, A. A. Ulson De Souza, Multicomponent adsorption and desorption of BTX compounds using coconut shell activated carbon: Experiments, mathematical modeling, and numerical simulation, Ind. Eng. Chem. Res. 52 (23) (2013) 7896-7911, doi: https://doi.org/10.1021/ie302849j.

28. A. D. P. Scheer, M. R. Mafra, A. Marcos, D. Canteli, D. Carpin, L. Igarashi-Mafra, Fixed-bed column adsorption of the coffee aroma compound benzaldehyde from aqueous solution onto granular activated carbon from coconut husk, LWT - Food Sci. Technol. 59 (2) (2014) 1-8, doi: https://doi. org/10.1016/j.Iwt.2014.06.015.

29. J. L. Sotelo, A. Rodríguez, S. Álvarez, J. García, Removal of caffeine and diclofenac on activated carbon in fixed bed column, Chem. Eng. Res. Des. 90 (7) (2011) 967-974, doi: https://doi.org/10.1016/j.cherd.2011.10.012.

30. J. M. Salman, V. O. Njoku, B. H. Hameed, Batch and fixedbed adsorption of 2,4-dichlorophenoxyacetic acid onto oil palm frond activated carbon, Chem. Eng. J. 174 (2011) 3340. doi: https://doi.org/10.1016/j.cej.2011.08.024.

31. J. L. Sotelo, G. Ovejero, A. Rodríguez, S. Álvarez, J. García, Analysis and modeling of fixed bed column operations on flumequine removal onto activated carbon: $\mathrm{pH}$ influence and desorption studies, Chem. Eng. J. 228 (2013) 102-113, doi: https://doi.org/10.1016/j.cej.2013.04.088.

32. T. M. Darweesh, M. J. Ahmed, Adsorption of ciprofloxacin and norfloxacin from aqueous solution onto granular activated carbon in fixed bed column, Ecotoxicol. Environ. Saf. 138 (2017) 139-145, doi: https://doi.org/10.1016/j. ecoenv.2016.12.032.

33. T. M. Darweesh, M. J. Ahmed, Batch and fixed bed adsorption of levofloxacin on granular activated carbon from date (Phoenix dactylifera L.) stones by $\mathrm{KOH}$ chemical activation, Environ. Toxicol. Pharmacol. 50 (2017) 159-166, doi: https://doi.org/10.1016/j.etap.2017.02.005.

34. A. H. Sulaymon, D. W. Abood, A. H. Ali, Removal of Phenol and Lead from Synthetic Wastewater by Adsorption onto Granular Activated Carbon in Fixed Bed Adsorbers : predication of Breakthrough Curves, Hidrology Curr. Res. 2 (4)
(2011), doi: https://doi.org/10.4172/2157-7587.1000120.

35. H. Nouri, A. Ouederni, Modeling of the Dynamics Adsorption of Phenol from an Aqueous Solution on Activated Carbon Produced from Olive Stones, IJCEA 4 (4) (2013) 254261, doi: https://doi.org/10.7763/IJCEA.2013.V4.306.

36. M. Masomi, A. Asghar, G. D. Najafpour, A. Rahman, B. Mohamed, Dynamic adsorption of phenolic compounds on activated carbon produced from pulp and paper mill sludge: experimental study and modeling by artificial neural network (ANN ), Desalin. Water Treat. 55 (6) (2015) 1453-1466, doi: https://doi.org/10.1080/19443994.2014.926834.

37. A. Kumar, H. M. Jena, Removal of methylene blue and phenol onto prepared activated carbon from Fox nutshell by chemical activation in batch and fixed-bed column, J. Clean. Prod. 137 (2016) 1246-1259, doi: https://doi.org/10.1016/j. jclepro.2016.07.177.

38. S. M. Anisuzzaman, A. Bono, D. Krishnaiah, Y. Z. Tan, A study on dynamic simulation of phenol adsorption in activated carbon packed bed column, J. King Saud Univ. Eng. Sci. 28 (1) (2016) 47-55, doi: https://doi.org/10.1016/j.jksues.2014.01.001.

39. M. Fan, F. Sze, G. Mckay, Enhanced mitigation of para-chlorophenol using stratified activated carbon adsorption columns, Water Res. 46 (3) (2011) 700-710, doi: https://doi. org/10.1016/j.watres.2011.11.039.

40. Y. Shao, H. Zhang, Y. Yan, Adsorption dynamics of $p$-nitrophenol in structured fixed bed with microfibrous entrapped activated carbon, Chem. Eng. J. 225 (2013) 481-488, doi: https://doi.org/10.1016/j.cej.2013.03.133.

41. J. Liu, Y. Yan, H. Zhang, Adsorption dynamics of toluene in composite bed with microfibrous entrapped activated carbon, Chem. Eng. J. 173 (2) (2011) 456-462, doi: https://doi. org/10.1016/j.cej.2011.08.004.

42. R. Yacef, A. Mellit, S. Belaid, Z. Şen, New combined models for estimating daily global solar radiation from measured air temperature in semi-arid climates: Application in Ghardaïa, Algeria, Energ. Convers. Manage. 79 (2014) 606-615, doi: https://doi.org/10.1016/j.enconman.2013.12.057

43. S. Keskes, S. Hanini, M. Hentabli, M. Laidi, Artificial Intelligence and Mathematical Modelling of the Drying Kinetics of Pharmaceutical Powders, Kem. Ind. 69 (2020) 137-152, doi: https://doi.org/10.15255/KUI.2019.038.

44. A. Abdallah, M. Laidi, S. Hanini, Novel approach for estimating solubility of solid drugs in supercritical carbon dioxide and critical properties using direct and inverse artificial neural network (ANN), Neural Comput. Appl. (n.d.), doi: https:// doi.org/10.1007/s00521-015-2038-1.

45. M. M. Mukaka, Statistics Corner: A guide to appropriate use of Correlation coefficient in medical research, Malawi Med. J. 24 (3) (2012) 69-71, url: https://www.ncbi.nlm.nih.gov/ pmc/articles/PMC3576830/.

46. J. Vimont, D. Mcnally, J. G. Wilkinson, The MMIFstat Statistical Analysis Package Version 1.0., 2010 (February).

47. U. Khair, H. Fahmi, S. Al Hakim, R. Rahim, Forecasting Error Calculation with Mean Absolute Deviation and Mean Absolute Percentage Error, J. Phys. Conf. Ser. 930 (2017) 012002, doi: https://doi.org/10.1088/1742-6596/930/1/012002.

48. D. G. Garson, Interpreting neural network connection weights, AI Expert 6 (1991) 46-51.

49. H. Benimam, C. S. Moussa, M. Hentabli, S. Hanini, M. Laidi, Dragonfly-Support Vector Machine for Regression Modeling of the Activity Coefficient at Infinite Dilution of Solutes in Imidazolium Ionic Liquids Using $\sigma$-Profile Descriptors, J. Chem. Eng. Data 65 (2020) 3161-3172, doi: https://doi. org/10.1021/acs.jced.0c00168. 


\section{SAŽETAK}

\section{Modeliranje umjetne neuronske mreže višesustavnom dinamičkom adsorpcijom organskih onečišćujućih tvari na aktivnom ugljenu \\ Yamin Mesellem, ${ }^{*}$ Abdallah El Hadj Abdallah, ${ }^{\text {M Maamar Laidi, }}$ Salah Hanini i Mohamed Hentablia}

Cilj ovog rada bio je modelirati višesustavnu dinamičku adsorpciju tehnikom umjetne inteligencije. Za izradu umjetne neuronske mreže (ANN) upotrijebljen je skup podataka prikupljen iz znanstvenih radova koji sadrže kinetiku dinamičke adsorpcije na aktivnom ugljenu. Ispitivani parametri bili su: molarna masa, početna koncentracija, brzina protoka, visina sloja, promjer čestica, površina BET, prosječni promjer pora, vrijeme i koncentracija bezdimenzijskih otpadnih voda. Rezultati su pokazali da je tijekom faze generalizacije dobiven optimiran ANN s visokim koeficijentom korelacije, $R=0,997$, korijenom srednje kvadratne pogreške RMSE $=0,029$ i srednjim apsolutnim odstupanjem $\operatorname{AAD}(\%)=1,810$. Dodatno, provedena je i analiza osjetljivosti primjenom metode inverzne umjetne neuronske mreže kako bi se proučio učinak svih ulaza na dinamičku adsorpciju. $\cup$ radu je provedena i sljedivost procijenjenih rezultata razvojem grafičkog korisničkog sučelja.

Ključne riječi

Umjetna neuronska mreža, dinamička adsorpcija, organske onečišćujuće tvari, aktivni ugljen

a Laboratory of Biomaterials and Transport Phenomena

(LBMPT), University Yahia Fares of Médéa, Algeria

${ }^{\mathrm{b}}$ Faculty of Science, University Saad Dahleb of Blida

(USDB-1-), Somaa, Blida, Algeria
Izvorni znanstveni rad Prispjelo 10. ožujka 2020. Prihvaćeno 1. srpnja 2020. 